\title{
AN EXPERIMENTAL EVALUATION OF PHOTOMETRIC PERFORMANCE AND POWER QUALITY OF LED LAMPS IN DIFFERENT OPERATING CONDITIONS
}

\author{
Gamal M. Dousoky ${ }^{1}$, Zeyad M. M. Ali ${ }^{3^{*}}$, A. M. Elsawy ${ }^{3}$ \\ ${ }^{1,2,3}$ Electrical Engineering Department, Faculty of Engineering, Minia University, Minia, Egypt. \\ *Corresponding author Email: eng.zeyadelkordy@yahoo.com
}

\begin{abstract}
Due to the global interest of Light Emitting Diode (LED) Technology, LED lamps manufacturers and academic researchers are doing great efforts to study different aspects of LED lamps performance. This paper investigates the photometric and electrical properties of LED lamps. The effect of temperature on the output light emitted from the LED lamps has been studied and a model of LED lamp is simulated and presented in this manuscript. The presented model has been implemented experimentally to investigate the lamp performance. Experimental results show that the effect of aging test on photometric parameters of LED lamp such as luminous flux, correlated color temperature (CCT), color rendering index (Ra). This study enables to understand and well control the features of the visible light emitted from LED lamps. The value of CCT is an important parameter in many applications such as lighting, videography, photography, publishing, horticulture, and manufacturing. It is desirable to achieve a high CRI light in color-critical applications such as neonatal care in hospitals). Experimental results also demonstrate that PF of LED lamp driver decrease when the lamp is operated in high ambient temperature.
\end{abstract}

Keywords: LED indoor lighting, Energy saving, Energy efficiency, Photometric characteristics, Aging test, Power quality.

\section{INTRODUCTION}

Light Emitting Diode or LED is a P-N junction diode, which emits light when activated. Today, LEDs are commonly used in different applications (lamps, TV's, camera flashes, traffic lights, displays, etc.)[1] [2].

Nowadays, LED lights have become an applicable lighting solution for indoor and outdoor applications [3]. Furthermore, with the technology advancements, all traditional lamps (incandescent bulbs, compact fluorescent lamps (CFLs), high intensity discharge lamps (HIDs), etc.) has been replaced with LEDs [4]. LED lamps consume only about $10 \%$ of the energy that incandescent lamps require [5]. Moreover, mass manufacturing has resulted in a significant drop in production cost of LEDs. LEDs have many advantages such as long lifetime, low power consumption and high efficacy [6].

Lighting purposes represent about 25\% of world electricity consumption. Hence, LED lamps contribute to save the Earth's resources [7].

In Egypt, residential, and street lighting sectors consume $50.5 \%$, and $4 \%$, respectively, of Egypt's total electricity consumption [8]. Lighting represents the largest proportion of household electricity consumption, as shown in Fig.1 and Fig.2. 
Vol. 39, No. 2. July 2020

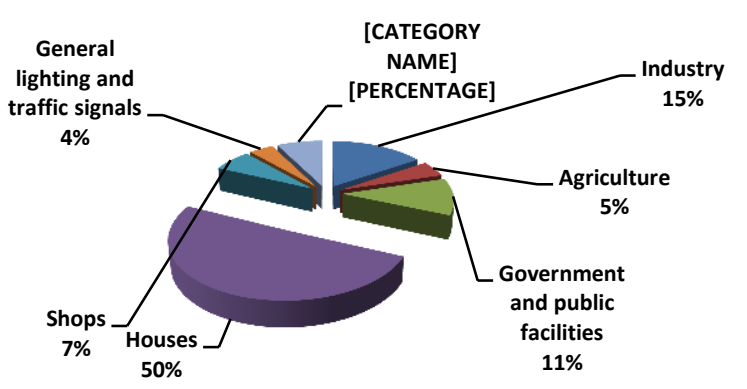

Fig.1. Percentage of electricity consumption in Egypt over different purposes (2016/2017).

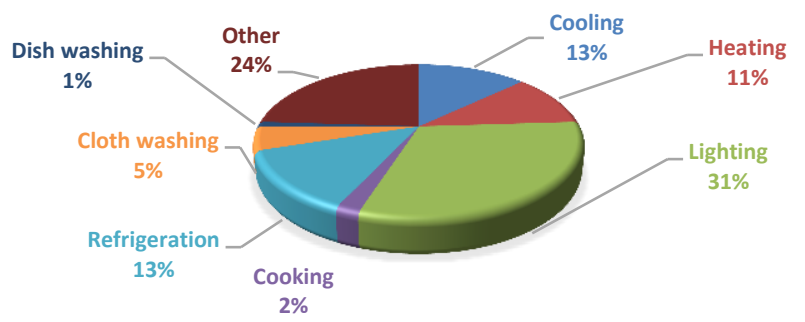

Fig.2. Percentage of electricity consumption in Egypt in residential sector.

There is an interest from countries around the world to use LED lamps. For example, in the first quarter of 2015, Ministry of Electricity and Renewable Energy in Egypt released an international tender to supply 13 million LED lamps with various power $(4 \mathrm{~W}, 6 \mathrm{~W}, 9 \mathrm{~W})$ to be sold to customers through Electricity Distribution Companies (EDCs) in different governorates of Egypt [9] in order to replace traditional lamps to LEDs.

As LEDs spread and becoming more and more popular, their characteristics getting well understood and considered. Study and investigation of LED performance under different conditions have been focused in many previous researches. However most of these handled the LED lamp as a separate unit: Some of these papers studied LED as P-N junction concept [1014], and other studied the LED lamp driver itself [15-17]. In this work, it is considered that LED lamp as a compact unit. However, the archival content of LEDs investigations and experimental tests is still limited. In this paper, the aging test is used to evaluate the reliability of LED lamps with respect to their output light performance characteristics. The following points are investigated in this paper:

- The relationship between DC LED current and luminous flux emitted from LED.

- The behavior of luminous flux versus time aging of LED lamps.

- The rate of change of correlated color temperature (CCT) with time aging of LED lamps.

- The behavior of color rendering index $(\mathrm{Ra})$ versus time aging of LED lamps.

- Power factor analysis of LED lamps with change of temperature.

- Construction and simulation of a proposed LED model.

This work is organized as follows: Section II presents the theoretical frame work. Section III provides experimental works. Section IV studies the relationship between luminous flux of LEDs and current. Luminous flux versus time is presented in section $\mathrm{V}$. The effect of time on two major parameters: correlated color temperature and color rendering index is discussed in sections VI and VII, respectively. Finally, section VIII investigates the impact of increasing temperature on power factor of LED lamp driver.

\section{Theoretical Framework}

\subsection{Current versus luminous flux}

Luminous flux of LEDs is function of forward current according to the following equation [17]:

$$
\operatorname{Lm}(I)=0.0001 I^{2}+0.3093 I+3.647
$$

where $L m$ refers to the luminous flux of LED and $I$ refers to the forward current of LED (Technical Datasheet DS56, Power Light Source Luxeon Rebel, Philips Lumileds Lighting) [17]. This Equation can be drown as in Fig.3; which shows light output versus current of a similar LED. 
Vol. 39, No. 2. July 2020

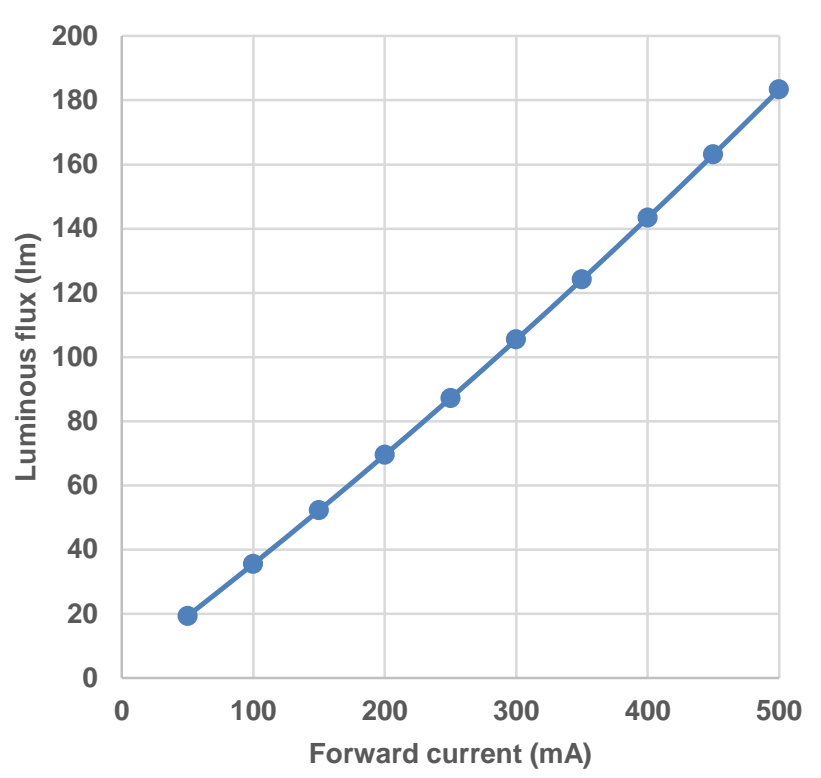

Fig.3. Light output versus current.

\subsection{Temperature versus current and luminous flux}

The forward current of LED is affected seriously by environment temperature according to the following equation [17]:

$$
I(\mathrm{~V}, \mathrm{~T})=\exp (-5.75564+3.6398 V-0.003(T-25))
$$

where:

I refers to the forward current of LED.

$V$ refers to the forward voltage of LED.

$T$ refers to the LED temperature.

And by changing temperature in this model from $0^{\circ} \mathrm{C}$ to $100^{\circ} \mathrm{C}$, the results can be obtained as shown in Fig. 4.

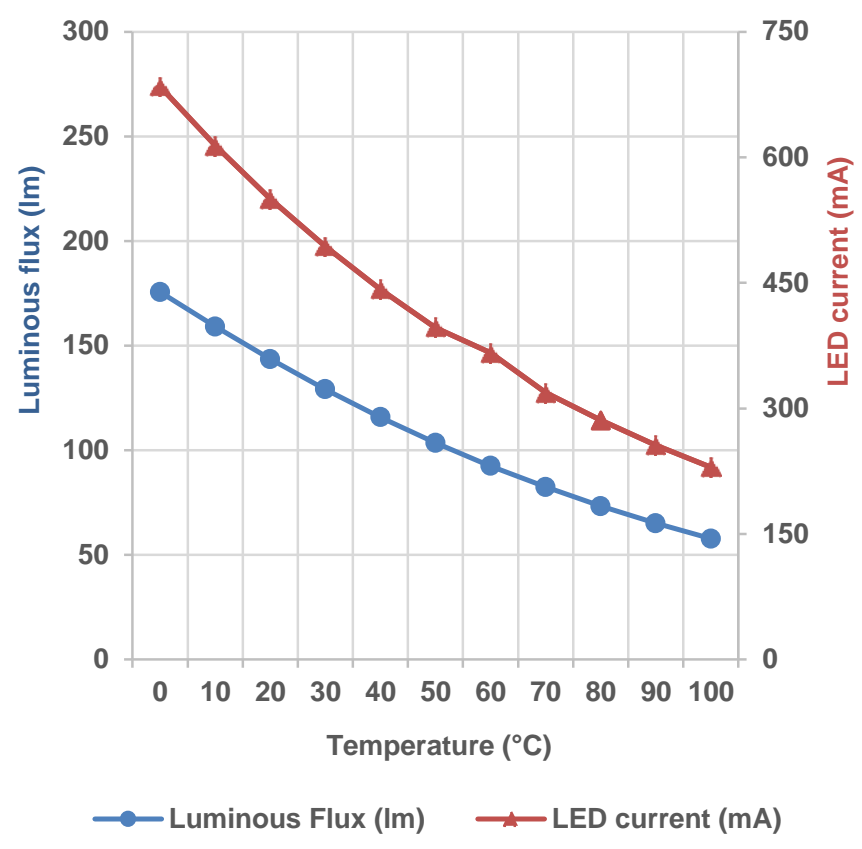

Fig.4. Luminous flux and LED current vs. temperature.

From the previous results, it has proved that luminous flux of LED is inversely proportional to temperature. This means that by increasing temperature, the luminous flux coming from LED will decrease. In other meaning, the forward current of LED has to be compensated in order to keep the luminous flux as desirable value.

\section{EXPERIMENTAL WORK}

\section{Experimental Setup:}

An experimental setup has been achieved to investigate the features under study. The setup includes the following devices:

1- Spectrophotocolor meter "Volnic FMS3000".

2- Photometer "HP200".

3- Digital power meter "HP105".

4- Constant current (DC power supply) "WP502".

5- AC power source "FDP-500".

6- Constant temperature and humidity chamber "JY-K-100T".

7- Heater.

8- Temperature sensor. 
Spectrophotocolor meter is used to measure LED photometric parameters such as lumen, correlated color temperature (CCT), color rendering index $(\mathrm{Ra})$ and the efficacy [18]. This device consists of a sphere and control unit to analyze the lamp luminous flux as shown in Fig. 5.

Digital power meter is used to measure electrical performance parameters (power, voltage, current, power factor) as shown in Fig. 6.

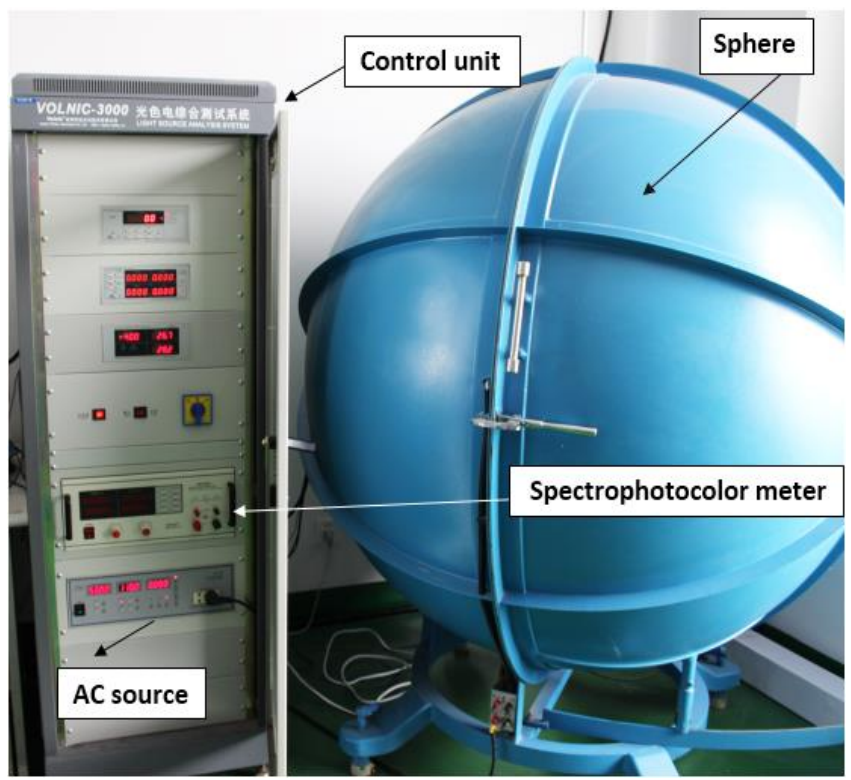

Fig.5. Volnic FMS-3000 spectrophotocolor meter.

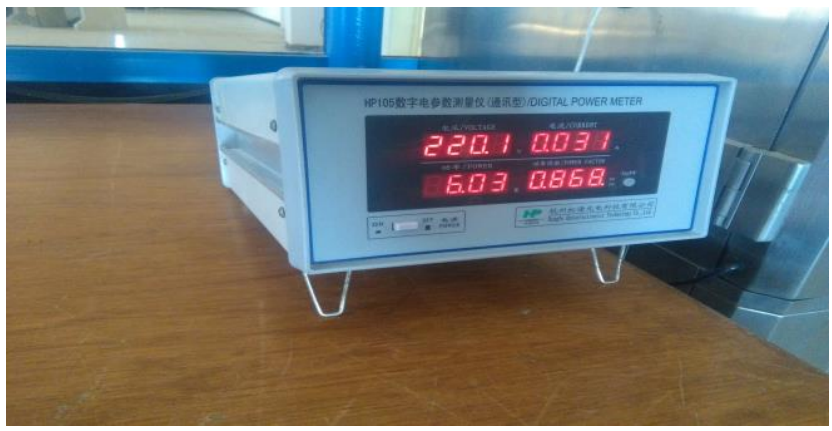

Fig.6. Digital power meter "HP105".

\section{Calibration procedures}

Before testing, calibration should be done, as follows:

- Calibration lamp is inserted inside the sphere.
- DC power supply is turned on and adjusted to constant 50V DC (according to lamp label).

- The lamp is left turned on for about 20 minutes to stabilize the luminous flux.

- Flux calibration is processed using the software "FMS-3000".

- Calibration is completed and then results are saved.

Fig.7 shows a humidity test chamber, where both temperature and humidity can be controlled in range from $0^{\circ} \mathrm{C}$ to $100^{\circ} \mathrm{C}$.

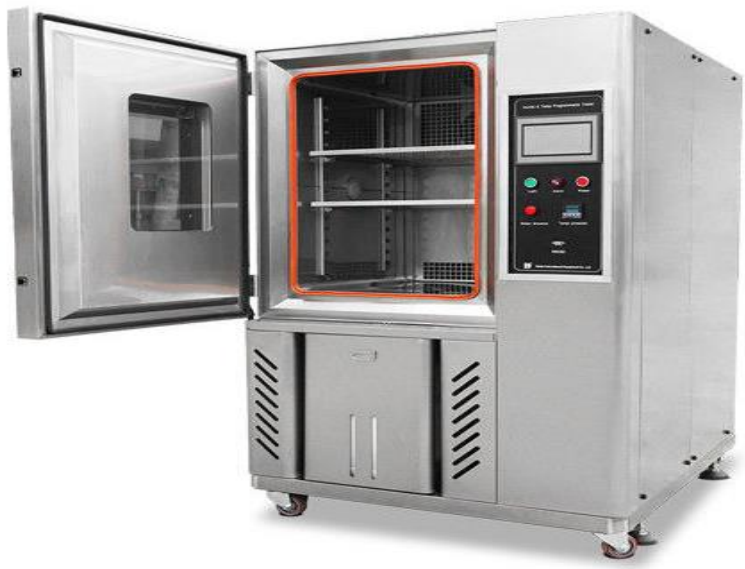

Fig.7. Temperature and humidity test chamber.

\section{Lamps under-test}

Two types of lamps have been tested: $60 \mathrm{~cm} 9 \mathrm{~W}$ LED tube lamp and 6W LED bulbs with different brands. These brands were chosen as they are the most popular ones in the Egyptian market. The lamps under test have different specifications (lumen, CCT and CRI) values.

\section{LED lamp components}

The main components of LED lamp are chip, driver and heat sink. There are some other secondary components of LED lamp such as housing and lamp base.

\section{LUMINOUS FLUX VS. CURRENT}

In this experiment, LED lamp $60 \mathrm{~cm}$ (Model 2835 (SMD) LEDs), operates with DC 
voltage is tested.

A constant DC voltage $(50 \mathrm{~V})$ is applied to the LED lamp and the current fed into the lamp is manually controlled and the change in luminous flux emitted from the lamp is noticed, measured, and recorded as shown in Fig. 8.

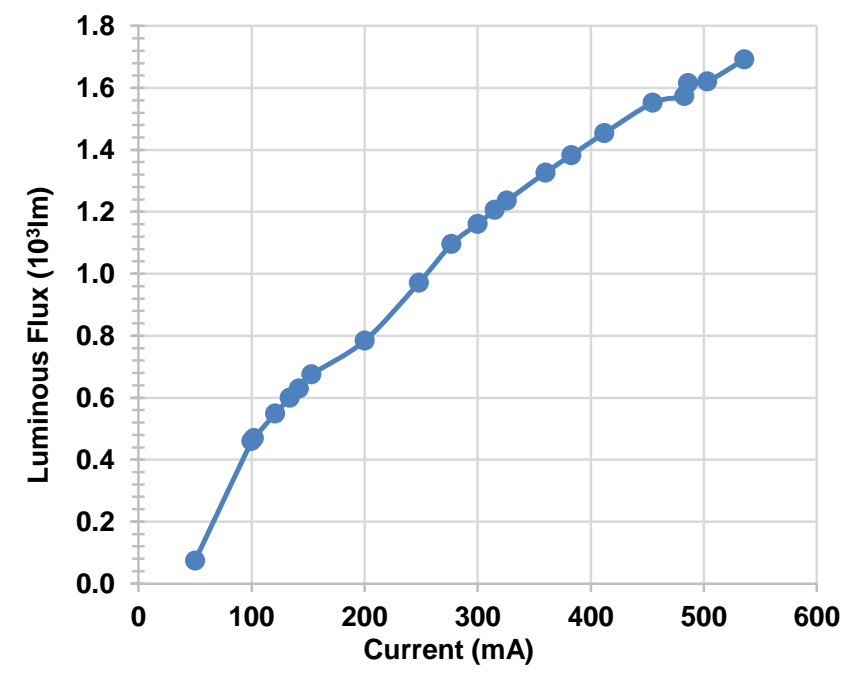

Fig.8. Experimental luminous flux vs. current.

\section{LUMINOUS FLUX VS. TIME}

In this experiment, six Watt LED bulbs with different brands are tested.

The samples are operated for 100 hours continuously and the change of luminous flux is observed, measured, and recorded, as shown, in Fig. 9.

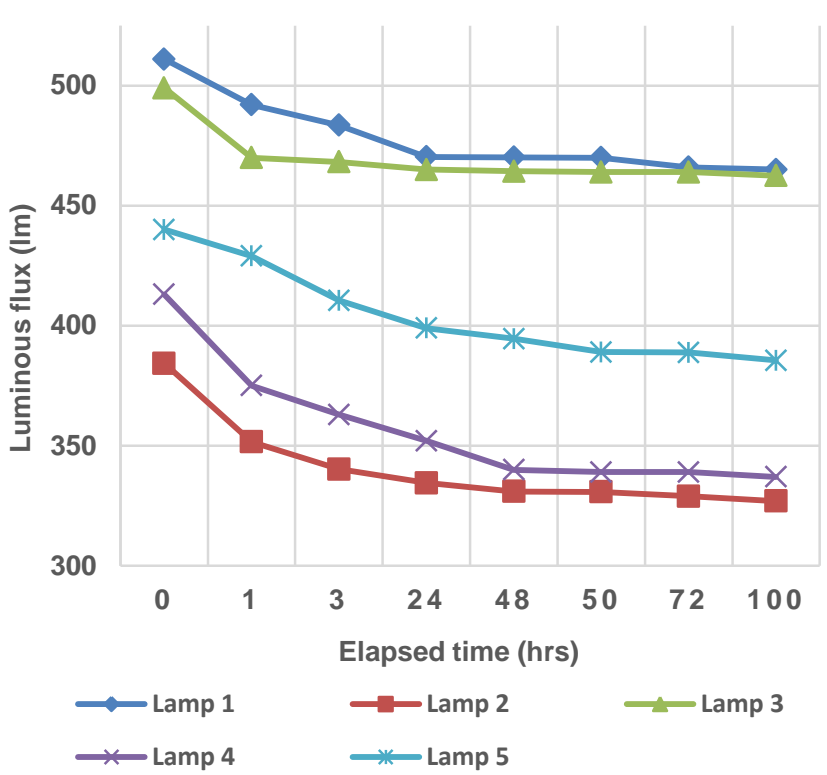

Fig.9. Luminous flux vs. Time.

CORRELATED COLOR TEMPERATURE (CCT) VS. TIME

The Correlated Color Temperature (CCT) is a more specific term used to describe the color of a light emitted by a light source. CCT is defined in Kelvin degrees; a warm light like sodium lamps is around $2700 \mathrm{~K}$, worm white is around $4000 \mathrm{~K}$, cool white is from $5000 \mathrm{~K}$ to $6500 \mathrm{~K}$, and the more than $6500 \mathrm{~K}$ is the blue light [1] [19], as shown in Fig. 10.

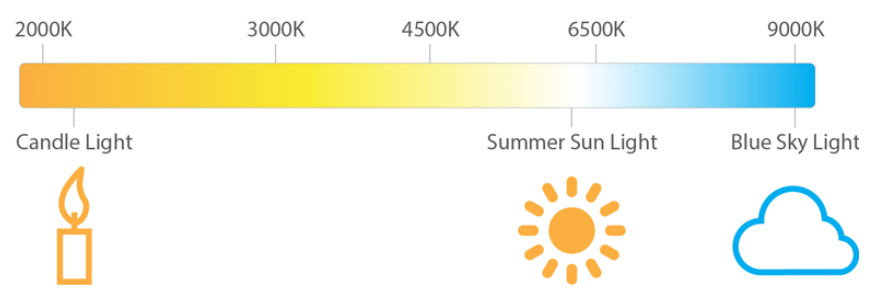

Fig.10. Correlated color temperature chart [20].

Color temperature is an important concept when purchasing a light source [21]. Selecting the right color temperature can make a big difference in choosing the suitable lamp for the area to be illuminated [22]. In this experiment, the samples are operated for 100 hours continuously. The change of CCT is observed, measured, and recorded, as shown in Fig. 11. 
Vol. 39, No. 2. July 2020

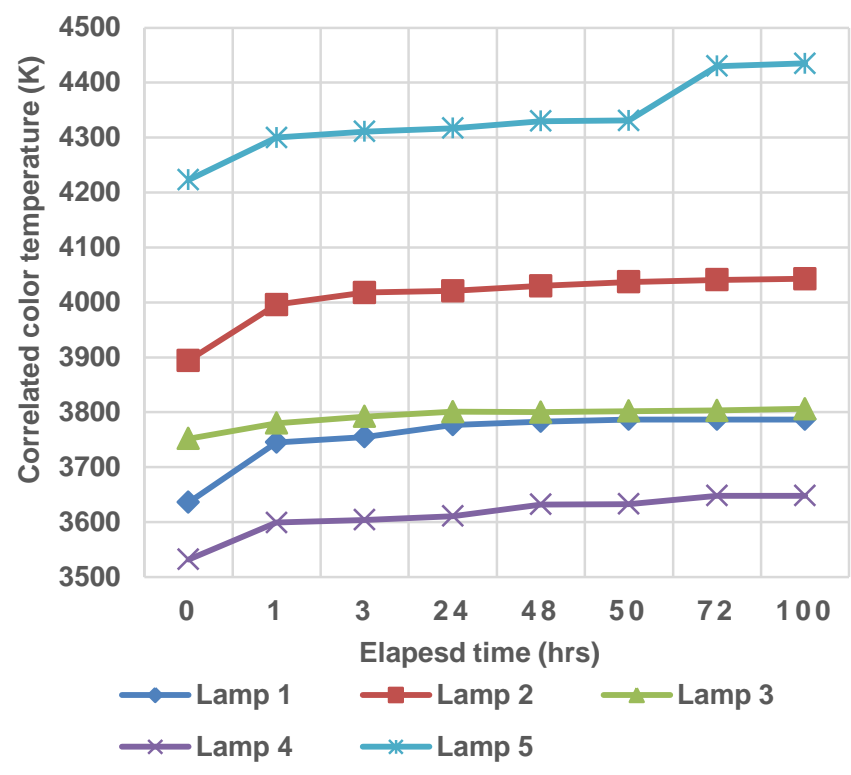

Fig.11. Correlated color temperature (CCT) vs. operating time.

The results obtained in this experiment reveals that CCT of LED lamps increases with the passage of time. This means that the color of light emitted from lamps changes. This may have an effect on the design of lighting in color-sensitive places where light color is important such as intensive care rooms in hospitals as well as in archaeological sites and museums.

\section{COLOR RENDERING INDEX VS. TIME}

Color Rendering Index (CRI) is an important parameter means a scale that measures the ability of a light source to faithfully reproduce color when compared to an ideal light source such as the sun and tungsten lamp. It shows how the color of an object appears to human eyes.it is a scale from 0 to 100 [23].

By operating the samples for 100 hours continuously, the change of CRI is observed, measured, and recorded.

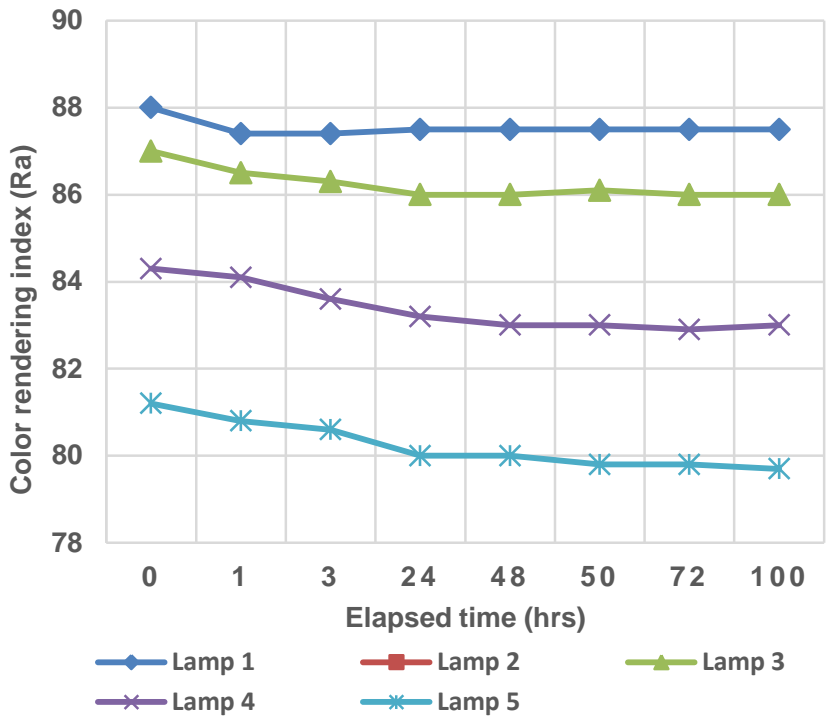

Fig.12. Color rendering index vs. operating time.

The experimental results, shown in Fig. 12, indicate that on the change in the CRI of the LED lamps is minor.

\section{EFFECT OF TEMPERATURE ON POWER FACTOR}

Power factor $(\mathrm{PF})$ is a key parameter in selecting the lamps [24]. Power factor is defined as the ratio of real or active power (in Watts) to apparent power (in VA);i.e. the lower power factor the higher drown current of the load [25]. By inserting the samples in temperature test chamber, changing the chamber temperature from $5^{\circ} \mathrm{C}$ to $90^{\circ} \mathrm{C}$, measuring the power factor of LED lamp driver by using digital power meter "HP105" and then recording the results as shown in Fig. 13 and Fig. 14. 
Vol. 39, No. 2. July 2020

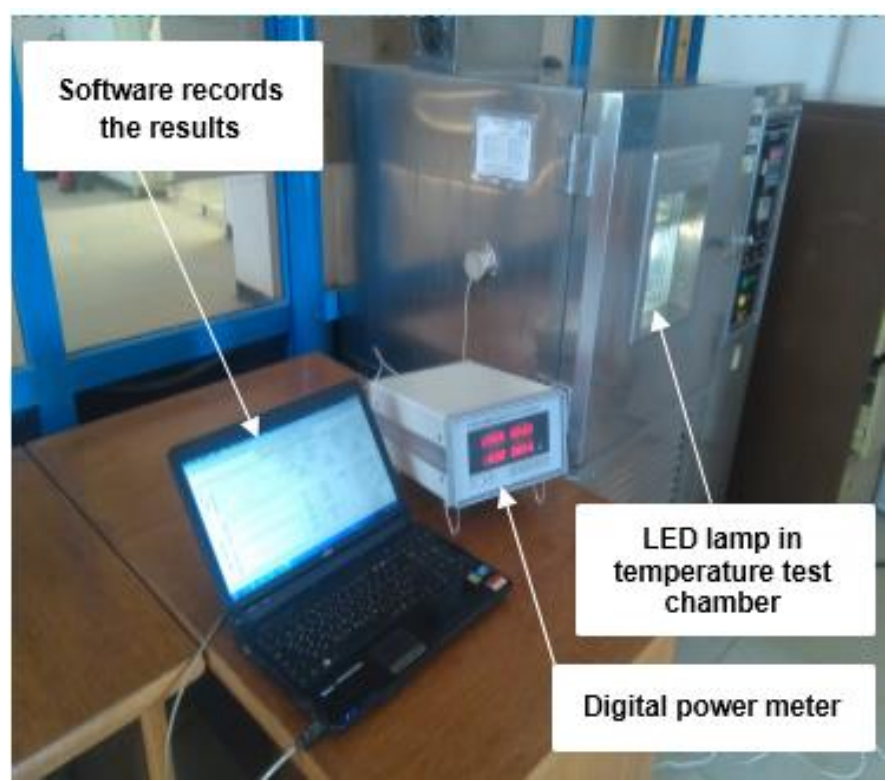

Fig.13. The chamber temperature uses for measuring the power factor of LED lamp.

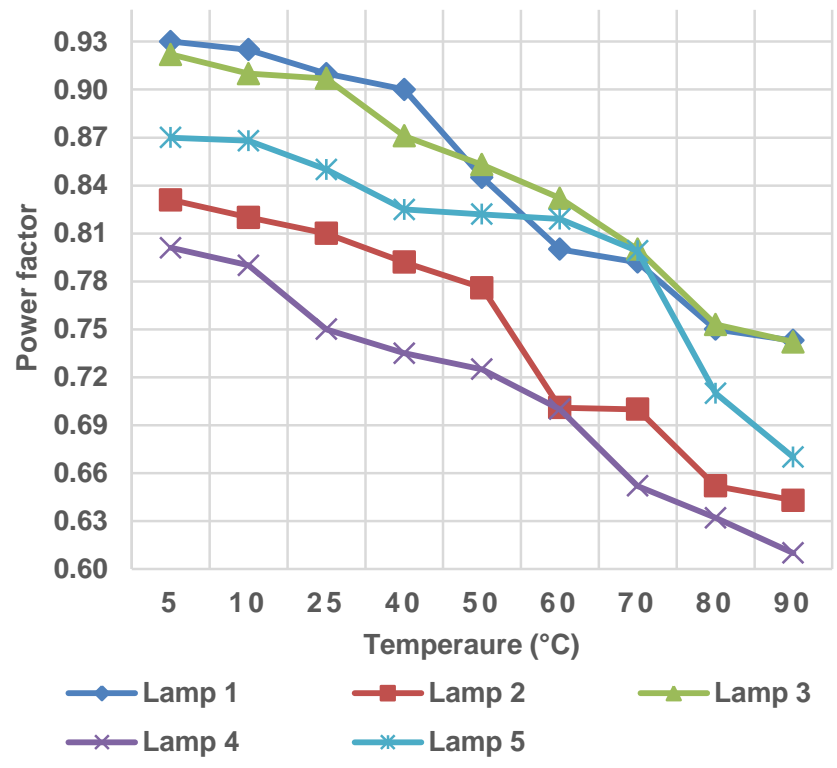

(a)

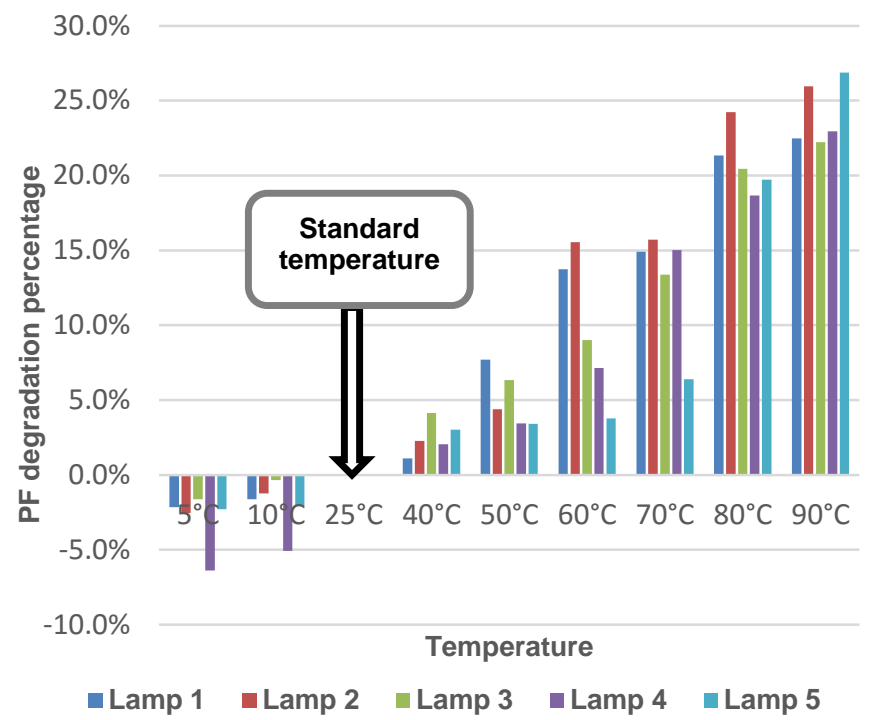

(b)

Fig.14. Effect of operating temperature on power factor of LED lamp driver: (a) PF vs. temperature, (b) PF degradation percentage from its value at standard temperature $\left(25^{\circ} \mathrm{C}\right)$.

From the previous experiment, it is shown that power factor of LED lamp driver decreases from about $1 \%$ to $26 \%$ over the temperature range of $5^{\circ} \mathrm{C}$ to $90^{\circ} \mathrm{C}$.

In some factories, especially heavy industries such as steel and cement factories, production lines are illuminated by LED lamps and these lamps work continuously at high temperatures. High temperature leads to a change in the characteristics of electronic components of the driver circuit. This leads to reduction of the power factor of the lamps as noticed in the previous experiment. In such case, power factor should be compensated to avoid the poor PF penalty imposed by the electricity company on big consumers [26]. Furthermore, in long transmission lines decreased PF may lead to unacceptable voltage drop at the receiving end and leads to electricity grid stability complications. Hence, LED lamps operating power factor is usually considered by heavy consumers as well as electric grid operators. 
Vol. 39, No. 2. July 2020

\section{ConClusion}

Several experimental investigations have been conducted in this research to explore and evaluate LED Lamps performance. Experimental results proved that when the DC forward current increases, luminous flux emitted from LED increases and vice-versa. Moreover results showed that by running LED lamps continuously and observation versus elapsed operating time, the LED lamps luminous flux is degraded, the correlated color temperature increases, and on the contrary, the color rendering index is approximately constant. Experimental results also showed that PF of LED lamp driver decreased when operating temperature increases.

This research recommends that luminous flux and CCT of LED lamps should be checked periodically to make sure that their values are still within acceptable limits. It is recommended to employ current compensation controllers such as boost converters to maintain luminous flux as desired. Furthermore, the authors recommend to use a power factor correction technique to compensate the degraded power factor due to the increased temperature working environment.

\section{REFERENCES}

[1] S. Pimputkar, J. S. Speck, S. P. DenBaars, and S. Nakamura, "Prospects for LED lighting," Nature photonics, vol. 3, p. 180, 2009.

[2] H.-C. Kim, M. C. Choi, S. Kim, and D.-K. Jeong, "An AC-DC LED driver with a twoparallel inverted buck topology for reducing the light flicker in lighting applications to low-risk levels," IEEE Transactions on Power Electronics, vol. 32, pp. 3879-3891, 2017.

[3] X. Qu, Q. Liu, H. Wang, and F. Blaabjerg, "System-Level Lifetime Prediction for LED Lighting Applications Considering Thermal Coupling Between LED Sources and Drivers," IEEE Journal of Emerging and Selected Topics in Power Electronics, vol. 6, pp. 1860-1870, 2018.

[4] C. R. Rodrigues, P. S. Almeida, G. M. Soares, J. M. Jorge, D. P. Pinto, and H. A. Braga, "An experimental comparison between different technologies arising for public lighting: LED luminaires replacing high pressure sodium lamps," presented at the 2011 IEEE International Symposium on Industrial Electronics, 2011.

[5] J. D. Bergesen, L. Tähkämö, T. Gibon, and S. Suh, "Potential long-term global environmental implications of efficient lightsource technologies," Journal of Industrial Ecology, vol. 20, pp. 263-275, 2016.

[6] H. Zhang, "A Viable Nontesting Method to Predict the Lifetime of LED Drivers," IEEE Journal of Emerging and Selected Topics in Power Electronics, vol. 6, pp. 1246-1251, 2018.

[7] I. Akasaki, H. Amano, and S. Nakamura, "The Nobel Prize in Physics 2014," The Royal Swedish Academy of Science, 2014.

[8] E. E. H. Company. (2019). Annual report. Available:

http://www.moee.gov.eg/test_new/report.aspx

[9] S. Abdulla, D. M. Said, K. Youssef, S. Hussien, and H. Waheed, "Saving energy and environment in residential sector," in Power

Systems Conference (MEPCON), 2017 Nineteenth International Middle East, 2017, pp. 603-606.

[10] Q. Chen, R. Hu, J. Hu, B. Xie, X. Yu, and X. Luo, "Experimental study of measuring LED's temperatures via thermocouple," in 2016 17th

International Conference on Electronic

Packaging Technology (ICEPT), 2016, pp. 880-883.

[11] Y.-K. Kuo, Y.-H. Shih, J.-Y. Chang, F.-M. Chen, M.-L. Lee, and J.-K. Sheu, "Theoretical investigation of efficient green tunneljunction light-emitting diodes," IEEE Electron Device Letters, vol. 38, pp. 75-78, 2017.

[12] X. Tao and B. Yang, "Study of junction temperature effect on electrical power of light-emitting diode (LED) devices," in 2015 IEEE 22nd International Symposium on the Physical and Failure Analysis of Integrated Circuits, 2015, pp. 430-433.

[13] X.-X. Wang, L. Jing, Y. Wang, Q. Gao, and Q. Sun, "The Influence of Junction Temperature Variation of LED on the Lifetime Estimation During Accelerated Aging Test," IEEE Access, vol. 7, pp. 47734781, 2019.

[14] J. Zhou, X. Long, J. He, F. Ren, and L. Fang, "Uncertainty Quantification for Junction 


\section{Vol. 39, No. 2. July 2020}

Temperature of Automotive LED With DieAttach Layer Microstructure," IEEE Transactions on Device and Materials Reliability, vol. 18, pp. 86-96, 2018.

[15] S. Chen, S. Ding, and H. Ye, "Driver circuit for an LED lighting tube, LED lighting tube and method for providing a controlled DC output power," ed: Google Patents, 2019.

[16] S.-W. Lee, H.-J. Choe, and J.-J. Yun, "Performance improvement of a boost LED driver with high voltage gain for edge-lit LED backlights," IEEE Transactions on Circuits and Systems II: Express Briefs, vol. 65, pp. 481-485, 2018.

[17] R. Lenk and C. Lenk, Practical lighting design with LEDs: John Wiley \& Sons, 2017.

[18] V. company. (2019). spectrophotocolor meter manual. Available: http://www.volnic.cn/index.php?s=/en/produc t/details/id/475

[19] Z. Guo, K. Liu, L. Zheng, T.-m. Shih, Y. Lu, $\mathrm{T}$. Wu, et al., "Investigation on three-hump phosphor-coated white light-emitting diodes for healthy lighting by genetic algorithm," IEEE Photonics Journal, vol. 11, pp. 1-10, 2019.

[20] H.-T. Chen, S.-C. Tan, and S. R. Hui, "Nonlinear dimming and correlated color temperature control of bicolor white LED systems," IEEE Transactions on Power Electronics, vol. 30, pp. 6934-6947, 2015.

[21] R. Malik, K. K. Ray, and S. Mazumdar, "Wide-Range, Open-Loop, CCT and Illuminance Control of an LED Lamp Using Two-Component Color Blending," IEEE Transactions on Power Electronics, vol. 33, pp. 9803-9818, 2018.

[22] H. Chen, X. Zhou, S. Lin, and J. Liu, "Luminous Flux and CCT Stabilization of White LED Device With a Bilevel Driver," IEEE Photonics Journal, vol. 10, pp. 1-10, 2018.

[23] T. Erdem, S. Nizamoglu, X. W. Sun, and H. V. Demir, "A photometric investigation of ultra-efficient LEDs with high color rendering index and high luminous efficacy employing nanocrystal quantum dot luminophores," Optics Express, vol. 18, pp. 340-347, 2010.

[24] E. S. Lee, B. H. Choi, J. P. Cheon, G. C. Lim, B. C. Kim, and C. T. Rim, "TemperatureRobust LC 3 Passive LED Drivers With Low
THD, High Efficiency and PF, and Long Life," IEEE Journal of Emerging and Selected Topics in Power Electronics, vol. 3, pp. 829840, 2015.

[25] T.-J. Liang, W.-J. Tseng, J.-F. Chen, and J.-P. $\mathrm{Wu}$, "A novel line frequency multistage conduction LED driver with high power factor," IEEE Transactions on Power Electronics, vol. 30, pp. 5103-5115, 2015.

[26] A. F. Zobaa and M. M. A. Aziz, "The most economical power factor correction according to tariff structures in Egypt," IEEE transactions on power delivery, vol. 20, pp. 912-918, 2005. 
تقييم معملي للأداء الضوئي وجودة القدرة للمبات الصمامات الثنائية الباعثة للضوء في ظروف تثغيل مختلفة نظرًا للاهتمام العالمي بتكنولوجيا الإضاءة الباعثة للضوء (LED) ، يبذل مصنعو لمبات LED والباحثون الأكاديميون جهودًا كبيرة لدراسة كل جانب من جوانب أداء هذا النوع من اللمبات.

تبحث هذه الرسالة في الخصائص الضوئية والكهربائية للمبات LED. وقد تثت دراسة تأثير درجة الحرارة على الضوء المنبعث منها، وتم محاكاة نموذج لمبات LED في هذه الرسالة. كما قدمت أيضا الرسالة نتائج تجريبية لتأثير اختبار التقادم (مرور الزمن) على التتغيرات الضوئية للمبات LED مثل التدفق الضوئي ودرجة حرارة اللون (CCT) ومؤشر تقديم اللون (CRI).

تمكن هذه الدراسة من فهم ومراقبة الضوء المرئي المنبعث من لمبات LED وتعد مهمة في العديد من التطبيقات حيث أن معامل درجة حرارة اللون (CCT) معامل هام في مجالات الإضاءة والفيديو والتصوير الفوتوغرافي والصناعة كما أنه من المرغوب فيه أيضا تحقيق قيمة عالية في مؤشر تقديم الألوان (CRI) وذلك في التطبيقات الحساسة للون مثل العناية بالأطفال حديثي الولادة في المستشفيات.

وقد أثبتت النتائج التجريبية أيضًا أن معامل القدرة لللمبة LED ينخفض إلى نسبة تصل إلى 26\% تقريبًا عن قيمته المقننة عند تشغيله في درجات حرارة عالية. 